\title{
QUALIFICATION OF SUPPLIERS IN A SELECTED PRODUCTION ENTERPRISE
}

\author{
Marzena KUCZYŃSKA-CHAŁADA ${ }^{1 *}$, Monika ODLANICKA-POCZOBUTT², \\ Roksana POLOCZEK ${ }^{3}$ \\ ${ }^{1}$ Silesian University of Technology, Faculty of Materials Engineering, Department of Production Engineering; \\ marzena.kuczynska-chalada@polsl.pl, ORCID: 0000-0002-5273-8328 \\ 2 Silesian University of Technology, Department of Organization and Management, Institute of Management, \\ Administration and Logistics; monika.odlanicka-poczobutt@polsl.pl, ORCID: 0000-0001-7834-1188 \\ ${ }^{3}$ Silesian University of Technology, Faculty of Materials Engineering, Department of Production Engineering; \\ roksana.poloczek@polsl.pl, ORCID: 0000-0002-4842-7949 \\ * Correspondence author
}

Purpose: Supply logistics in an enterprise is extremely important because regardless of the business profile, all enterprises purchase materials, semi-finished products, raw materials or various types of services on the market. Typically, the amount of purchased assortment is so large that it can be stated that the share of materials in the total costs of the company is significant. The indicator of a modern enterprise is the number of clients and their level of satisfaction, which is why quality is a key factor for each production company (KuczyńskaChałada, and Furman, 2016) and an important element of process improvement is also an aspect of work safety (Małysa et al., 2019). The purpose of this article is to show that the process of choosing a reliable supplier does not end with choosing the supplier that offers the lowest rates for materials, but other elements that should be considered when choosing a supplier.

Design/methodology/approach: This is a research paper and the author presents the process of suppliers' qualification using the specified supplier evaluation criteria.

Findings: Before writing the paper we put a hypothesis stating an important feature of the supplier should be flexibility and readiness to change, develop and implement new solutions, because the supplier should strive for the customer.

Research limitations/implications: This is a research paper and the author utilized survey method.

Practical implications: What criteria determine the selection of the best supplier for the enterprise.

Keywords: logistics, orders, supply, classification.

Category of the paper: Research paper. 


\section{Identification and evaluation of suppliers}

After verifying the material demand and making a purchase decision from external sources, it is necessary to search for potential suppliers and their evaluation. The initiation of this process consists in creating a list of suppliers, based on such sources as: (Skowronek, 2008):

- information from sales representatives,

- trade press,

- catalogues of materials available on the market,

- directories,

- offers,

- information from exhibitions and fairs,

- advertising brochures,

- company's database,

- advertisements on the Internet,

- information obtained through business intelligence.

The following criteria may be used to assess potential suppliers (Zakrzewski, and Zakrzewska, 2014):

- the ability to design and carry on the process - this is an important criterion, especially when the company expects the supplier to design and produce a particular part. Establishing cooperation with such enterprises will allow to shorten the time of development of new products;

- the level of management staff - the qualities of the staff can reflect the experience and the ability of the company's employees, willingness to establish cooperation with a potential client as well as the quality of services provided;

- financial condition and cost structure - the assessment of the potential supplier's condition allows to eliminate threats related to entering into business relations with a partner who is in a disadvantaged financial position;

- planning and control system - having, by a potential supplier, a system for planning and controlling workflow in an organization can be a determinant of the efficiency of their work, which affects the efficiency of the supply chain;

- compliance with environmental protection regulations - compliance with environmental regulations by a potential supplier may be an important criterion for selecting a supplier of materials, because environmental awareness of the impact of industry on the natural environment is increasing;

- the possibility of establishing long-term cooperation - establishing cooperation is important when the supplier has proprietary technology or has access to foreign markets. 
The selection of purchase sources is one of the main supplying problems of an enterprise. The basic criterion in the selection of suppliers should be to minimize the total costs associated with the purchase of materials and maintenance of inventory, as well as to organize the necessary conditions for running smooth production while ensuring the supply of full-value production materials (Kowalska, 2005).

Creating an analysis divided into particular criteria, with the assigned significance for the company, allows to obtain a lot of information about cooperation with individual suppliers. Analysis of suppliers on the basis of archived data clearly presents errors and exposes new supply perspectives. The essential elements influencing the assessment and selection process of the supplier are presented in Fig. 1. Modeling cooperation with suppliers can also be based on CRM (Customer Relationship Management) experience (Odlanicka-Poczobutt 2016).

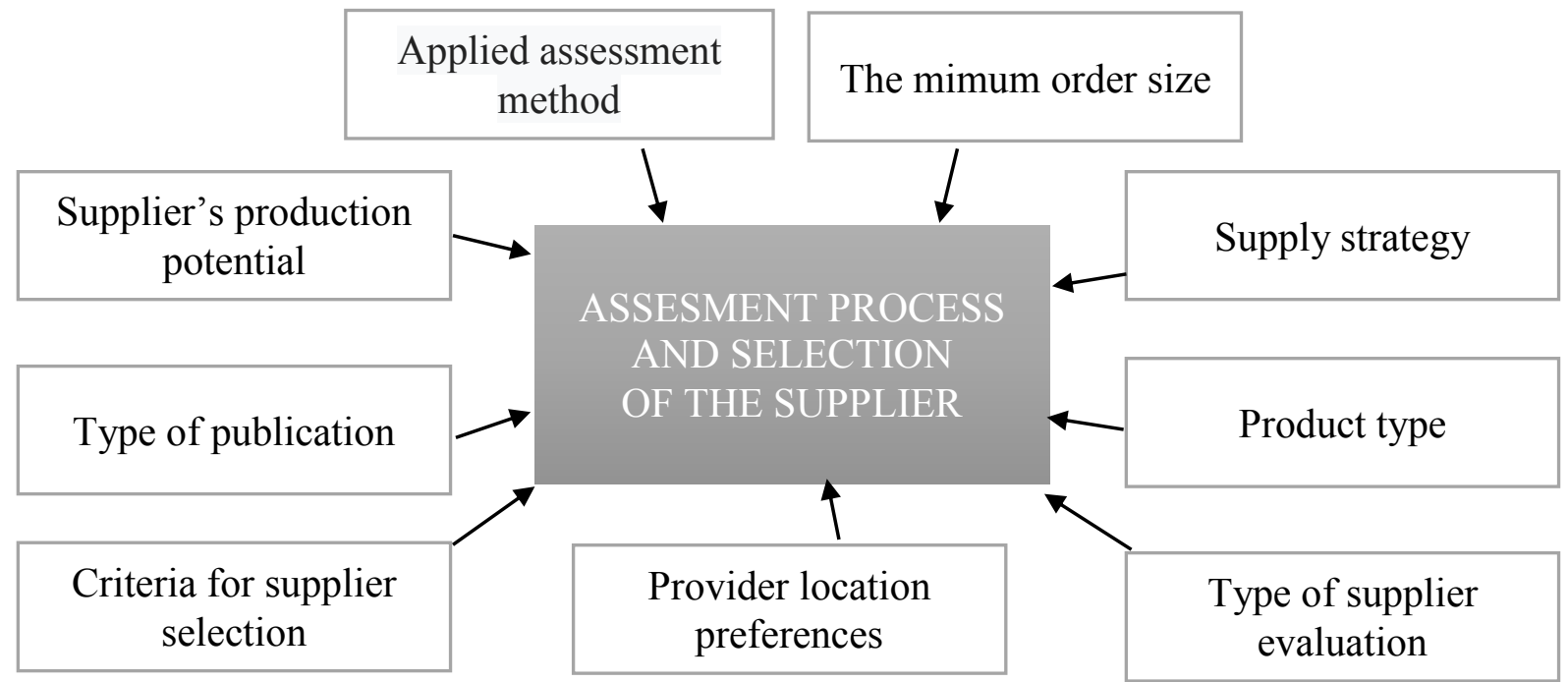

Figure 1. Elements affecting the supplier's evaluation and selection process. Adapted from: "Review of evaluation methods and selection of suppliers in the enterprise" by T. Nowakowski, S. WerbińskaWojciechowska. Copyright 2012 by Publisher.

The supplier's assessment should be carried out regularly in order to obtain current information in order to identify supplier's strengths and weaknesses, to implement corrective actions in the event of identifying infringements, to introduce improvement actions (Wolniak, and Skrotnicka - Zasadzień, 2008). The assessment of suppliers is aimed at:

- choosing the best supplier that will meet the company's expectations,

- motivation of suppliers at whom the process of deliveries and services needs adjustment,

- eliminating suppliers whose services and products do not meet the buyer's requirements (Bozarth, and Handfield, 2007).

When evaluating potential suppliers, the purchase department has the possibility to use methods that support decision making (Kowalska, 2005). For each supplier evaluation method, it is crucial to establish a list of criteria that will be the basis for qualifying the supplier. In each industry, the basic criteria may change as buyers classify suppliers according to their own preferences (Burdzik, 2017). The supplier's assessment may be based on the following criteria: 
a) price:

- price level in relation to the competition,

- payment conditions,

- price discounts,

- cost of delivery,

b) timeliness of deliveries:

- delivery time,

- keeping deadlines,

- flexibility in relation to a customer,

- supplier's location.

c) quality:

- the level of customer service,

- the level of product's quality,

- quality guarantees/complaints,

- production standards.

d) additional aspects:

- maintaining stocks,

- own transport,

- available assortment,

- technical competences,

- financial condition,

- mutual agreement,

- customer approach,

- following the procedures,

- production capacity,

- way of packaging,

- innovation,

- communication system (Burdzik, 2017).

\section{Choosing a supplier of materials and services}

After the evaluation of potential suppliers, you can make the final choice of the product or service provider. Selected manufacturing companies have a database in which the suppliers who have the best chance of placing orders are listed. These suppliers are selected on the basis of experience, where they could demonstrate their effectiveness and provide high quality services in the implementation of existing orders. When the enterprise has such a list of suppliers, the purchasing department has the ability to quickly identify reliable suppliers. 
However, in the absence of the database, the choice of the supplier will take place through the distribution of inquiries (calls for placing orders) or the organisation of tenders (Bozarth, and Handfield, 2007). After the company has collected the appropriate number of offers, the next step in choosing the supplier is their selection. Due to it, the most beneficial proposals are highlighted. When selecting offers, the following is taken into account:

- opinion about the potential supplier who submitted the offer,

- technical preparation and readiness of the potential supplier for technological and quality delivery,

- the supplier's ability to produce or deliver the required quantity of goods at the right time and in specified batches.

One negative evaluation should eliminate the tenderer from the further tenders contest. Pre-selection of offers allows to start negotiations as the final stage of the supplier selection process (Bendkowski, and Kramarz, 2011).

Procurement negotiations mainly concern (Bendkowski, and Kramarz, 2011):

- technical arrangements - convincing the buyer that the supplier is able to ensure the supply of materials in the right quantity and quality,

- organisational arrangements - supplier's possibilities to ensure timely delivery of materials,

- techniques of transport and reloading of goods - determining which side is to ensure the transport of goods, and whether special packaging of goods is required,

- rules of qualitative and quantitative acceptance, rules for reporting complaints and possible damages in this respect,

- products prices.

\section{The analysis of current system of evaluation and classification of suppliers in an enterprise - proposal of solutions}

The researched company is one of the largest manufacturers of LPG tanks in Poland and many complex large-size constructions for the steel, cement, sugar and energy industries.

The process of qualifying suppliers in an enterprise is used for two types of assessment:

- assessment of a new supplier - where the purchase is made for the first time,

- assessment of a qualified supplier - periodic.

The purpose of qualifying suppliers and contractors in the discussed company is to ensure the required quality properties of materials, products, processes and services performed.

A purchasing office employee collects data for qualifications based on analysis of suppliers' self-assessment questionnaires - self-assessment consists in completing a survey by the supplier, the purpose of which is to collect the necessary information about the organization, 
competence and technological capabilities of a given supplier to meet the requirements of the company. The supplier's self-assessment consists in providing the most up-to-date information about the supplier to the purchasing office employee, as this organizational unit is responsible for selecting the best supplier for the company.

The supplier self-assessment process consists of the following steps:

- sending in an electronic version to the supplier "Qualifying questionnaire of the supplier and contractor of services" in Polish or English language version,

- sending a cover letter, which contains information for the supplier regarding the essence of the self-assessment and the deadline for delivery of the completed questionnaire to the enterprise,

- feeling in the questionnaire by the supplier,

- receiving the completed "Qualifying questionnaire of the supplier and the contractor of the services" along with any accompanying documentation (copies of the certificates currently held by the supplier.) Copies of surveys and documentation are stored in the database on the enterprise network disk,

- carrying out the supplier's evaluation based on the supplier's self-assessment questionnaire, giving the supplier the right status,

- the result of the audit, which is carried out at selected suppliers - the supplier's audit is aimed at verifying the competences, as well as the supplier's possibilities in technical and organizational terms,

- delivery receipt results,

- information obtained from heads of organizational units (in the scope of services) and users of goods,

- market information,

- own supervision carried out by employees of the purchasing office,

- allowances and permits resulting from legal provisions held by a potential supplier.

Evaluation of external suppliers and service providers is performed once a year by a purchasing office employee and then approved by the supervisor. This supervisor makes the final decision regarding the qualification of the supplier or service provider.

Documents that support the supplier evaluation process in the enterprise:

- supplier's self-assessment questionnaire,

- table of verification,

- procedure,

- timeliness of deliveries sheet.

The aim of the current supplier assessment system is to ensure that the purchased product meets the specified requirements and ensures good cooperation with suppliers. After observing the functioning of the current supplier's assessment and qualification system in the company, it was analysed and the following observations were made: the scoring process is not appropriate for the specificity of the company. Each of the criteria has different meanings for 
the company, so they should be given equivalent weight of importance for the company. Assigning weights to individual criteria will also allow for a more accurate evaluation of suppliers. The list of criteria for the supplier should also be extended (the offer of criteria for the supplier together with the weights are presented in (Table 1). It is also proposed to change the evaluation of scoring system along with the characteristics (Table 2).

Table 1.

Qualities and criteria for a supplier

\begin{tabular}{|c|c|c|}
\hline Quality & Criterion & Weight [\%] \\
\hline Price & $\begin{array}{ll}\text { - } & \text { Price level } \\
\text { - } & \text { Payment terms } \\
\text { - } & \text { Price discounts } \\
\text { - } & \text { Delivery cost } \\
\end{array}$ & $35 \%$ \\
\hline Timeliness of deliveries & $\begin{array}{ll} & \text { Delivery time } \\
\text { - } & \text { Keeping deadlines } \\
\text { - } & \text { Flexibility of deliveries } \\
\text { - } & \text { Supplier's location }\end{array}$ & $20 \%$ \\
\hline Quality & $\begin{array}{l}\text { - Level of customer service } \\
\text { - } \quad \text { Quality level of products' } \\
\text { - Quality guarantees } \\
\text { - } \quad \text { Certification and licenses }\end{array}$ & $30 \%$ \\
\hline Additional features & $\begin{array}{ll}\text { - } & \text { Maintaining stock levels for a customer } \\
\text { - } & \text { Deliveries on own behalf } \\
\text { - } & \text { Diversity of assortment } \\
\text { - } & \text { Technical capabilities } \\
\text { - } & \text { Financial conditions } \\
\end{array}$ & $15 \%$ \\
\hline
\end{tabular}

Table 2.

Change the evaluation of scoring system along with the characteristics

\begin{tabular}{|c|c|c|c|c|c|}
\hline \multirow{2}{*}{ Criterion } & \multicolumn{5}{|c|}{ Score } \\
\hline & 1 & 2 & 3 & 4 & 5 \\
\hline Price level & $\begin{array}{l}\text { The highest } \\
\text { price of } \\
\text { products, after } \\
\text { which the } \\
\text { purchase is } \\
\text { unfavourable } \\
\text { and will bring } \\
\text { losses to the } \\
\text { company }\end{array}$ & $\begin{array}{l}\text { The price is high } \\
\text { compared to the } \\
\text { competition. } \\
\text { Buying at this } \\
\text { price is } \\
\text { unprofitable for } \\
\text { the company }\end{array}$ & $\begin{array}{l}\text { The price is } \\
\text { relatively low, } \\
\text { comparable to } \\
\text { market prices }\end{array}$ & $\begin{array}{l}\text { Favourable price } \\
\text { compared to the } \\
\text { competition. } \\
\text { Buying at this } \\
\text { price is } \\
\text { profitable. }\end{array}$ & $\begin{array}{l}\text { The lowest price } \\
\text { level on the } \\
\text { market. } \\
\text { Purchasing at } \\
\text { this price is the } \\
\text { most profitable } \\
\text { for the company. }\end{array}$ \\
\hline $\begin{array}{l}\text { Payment } \\
\text { terms }\end{array}$ & $\begin{array}{c}\text { Very } \\
\text { unfavourable, } \\
\text { no negotiable } \\
\text { conditions and } \\
\text { limited payment } \\
\text { options }\end{array}$ & $\begin{array}{l}\text { Unfavourable, } \\
\text { no negotiable } \\
\text { conditions }\end{array}$ & $\begin{array}{c}\text { Payment terms } \\
\text { comparable to } \\
\text { the competition, } \\
\text { it is possible to } \\
\text { negotiate. }\end{array}$ & $\begin{array}{l}\text { Favourable } \\
\text { payment terms, } \\
\text { in many aspects } \\
\text { better than } \\
\text { at competition. }\end{array}$ & $\begin{array}{l}\text { Very attractive } \\
\text { payment terms. } \\
\text { Better than } \\
\text { at competition. }\end{array}$ \\
\hline $\begin{array}{c}\text { Price } \\
\text { discounts }\end{array}$ & $\begin{array}{l}\text { No price } \\
\text { discounts, } \\
\text { no possibility to } \\
\text { negotiate }\end{array}$ & $\begin{array}{l}\text { Occasional price } \\
\text { discounts, there } \\
\text { is no possibility } \\
\text { of negotiating }\end{array}$ & $\begin{array}{l}\text { Price discounts } \\
\text { comparable to } \\
\text { most companies, } \\
\text { there is } \\
\text { a possibility of } \\
\text { negotiations }\end{array}$ & $\begin{array}{c}\text { Ability to } \\
\text { negotiate price } \\
\text { discounts better } \\
\text { than the } \\
\text { competition }\end{array}$ & $\begin{array}{l}\text { Very attractive } \\
\text { price discounts, } \\
\text { much better than } \\
\text { at competition }\end{array}$ \\
\hline
\end{tabular}


Cont. table 2.

\begin{tabular}{|c|c|c|c|c|c|}
\hline $\begin{array}{l}\text { Delivery } \\
\text { cost }\end{array}$ & $\begin{array}{l}\text { High delivery } \\
\text { costs, despite the } \\
\text { value of the } \\
\text { order }\end{array}$ & $\begin{array}{l}\text { Cost of delivery } \\
\text { is always } \\
\text { charged despite } \\
\text { the value of the } \\
\text { order }\end{array}$ & $\begin{array}{l}\text { Delivery costs } \\
\text { comparable to } \\
\text { the competition, } \\
\text { depending on } \\
\text { the value of the } \\
\text { order }\end{array}$ & $\begin{array}{l}\text { Most deliveries } \\
\text { are made at the } \\
\text { expense of the } \\
\text { supplier despite } \\
\text { the value of the } \\
\text { order }\end{array}$ & $\begin{array}{l}\text { All deliveries } \\
\text { are made at the } \\
\text { expense of the } \\
\text { supplier }\end{array}$ \\
\hline $\begin{array}{l}\text { Delivery } \\
\text { time }\end{array}$ & $\begin{array}{l}\text { Very long } \\
\text { delivery time, } \\
\text { need to order } \\
\text { very well in } \\
\text { advance }\end{array}$ & $\begin{array}{l}\text { Long delivery } \\
\text { time, need to } \\
\text { order well in } \\
\text { advance }\end{array}$ & $\begin{array}{l}\text { Delivery time } \\
\text { comparable to } \\
\text { the competition }\end{array}$ & $\begin{array}{l}\text { A large part of } \\
\text { deliveries is } \\
\text { carried out in } \\
\text { a short time }\end{array}$ & $\begin{array}{l}\text { Short delivery } \\
\text { time. All } \\
\text { deliveries are } \\
\text { made in a } \\
\text { shorter time than } \\
\text { the competition }\end{array}$ \\
\hline $\begin{array}{l}\text { Keeping } \\
\text { deadlines }\end{array}$ & $\begin{array}{l}\text { The supplier } \\
\text { repeatedly has } \\
\text { not delivered the } \\
\text { products on } \\
\text { time. Very long } \\
\text { delays }\end{array}$ & $\begin{array}{l}\text { The timeliness } \\
\text { of deliveries } \\
\text { raises many } \\
\text { objections, as } \\
\text { the goods are } \\
\text { often not } \\
\text { delivered on } \\
\text { time. Long } \\
\text { delays in order } \\
\text { fulfilment }\end{array}$ & $\begin{array}{l}\text { The supplier has } \\
\text { been late several } \\
\text { times with the } \\
\text { fulfilment of the } \\
\text { order, usually } \\
\text { orders are } \\
\text { processed on } \\
\text { time }\end{array}$ & $\begin{array}{l}\text { The supplier } \\
\text { performs orders } \\
\text { on time. There } \\
\text { were only } \\
\text { isolated cases of } \\
\text { short delays }\end{array}$ & $\begin{array}{c}\text { The goods are } \\
\text { always delivered } \\
\text { on time. } \\
\text { The supplier has } \\
\text { never been late } \\
\text { with the delivery }\end{array}$ \\
\hline $\begin{array}{l}\text { Flexibility } \\
\text { of delivery }\end{array}$ & $\begin{array}{l}\text { No flexibility. } \\
\text { In the case of } \\
\text { a request to } \\
\text { change the } \\
\text { conditions of the } \\
\text { order, there is no } \\
\text { possibility of } \\
\text { changes }\end{array}$ & $\begin{array}{l}\text { Low flexibility. } \\
\text { In the event of } \\
\text { a request to } \\
\text { change the order } \\
\text { conditions, there } \\
\text { are occasional } \\
\text { instances of } \\
\text { change }\end{array}$ & $\begin{array}{l}\text { Supplier's } \\
\text { flexibility } \\
\text { comparable to } \\
\text { the competition. } \\
\text { The possibility } \\
\text { of making } \\
\text { changes to the } \\
\text { order in selected } \\
\text { cases }\end{array}$ & $\begin{array}{l}\text { High flexibility } \\
\text { of the supplier. } \\
\text { In most orders, } \\
\text { it is possible to } \\
\text { change the terms } \\
\text { of the order }\end{array}$ & $\begin{array}{l}\text { Very high } \\
\text { flexibility of the } \\
\text { supplier. For all } \\
\text { orders revision } \\
\text { and changes can } \\
\text { be performed }\end{array}$ \\
\hline $\begin{array}{l}\text { Supplier's } \\
\text { location }\end{array}$ & $\begin{array}{l}\text { The company is } \\
\text { located very far } \\
\text { from the buyer. } \\
\text { Difficult access }\end{array}$ & $\begin{array}{l}\text { Supplier located } \\
\text { at a considerable } \\
\text { distance from } \\
\text { the buyer }\end{array}$ & $\begin{array}{c}\text { Supplier located } \\
\text { at a distance like } \\
\text { most competing } \\
\text { companies }\end{array}$ & $\begin{array}{l}\text { A supplier } \\
\text { located close to } \\
\text { the buyer }\end{array}$ & $\begin{array}{l}\text { Supplier located } \\
\text { very close to the } \\
\text { buyer }\end{array}$ \\
\hline $\begin{array}{c}\text { Level of } \\
\text { customer } \\
\text { service }\end{array}$ & $\begin{array}{l}\text { Very low level } \\
\text { of customer } \\
\text { service. } \\
\text { The supplier } \\
\text { does not pay } \\
\text { attention to the } \\
\text { buyer's } \\
\text { requirements. } \\
\text { Very low } \\
\text { communication }\end{array}$ & $\begin{array}{l}\text { Low level of } \\
\text { customer } \\
\text { service. Low } \\
\text { communicativen } \\
\text { ess regarding the } \\
\text { implementation } \\
\text { of orders and } \\
\text { requirements }\end{array}$ & $\begin{array}{l}\text { The level of } \\
\text { customer service } \\
\text { is medium, the } \\
\text { communicativen } \\
\text { ess of the } \\
\text { delivery is } \\
\text { comparable to } \\
\text { the competition }\end{array}$ & $\begin{array}{l}\text { High level of } \\
\text { customer } \\
\text { service. } \\
\text { The supplier is } \\
\text { communicative }\end{array}$ & $\begin{array}{l}\text { Very high level } \\
\text { of customer } \\
\text { service. The } \\
\text { communication } \\
\text { of the supplier is } \\
\text { very high. } \\
\text { The supplier } \\
\text { considers the } \\
\text { needs and } \\
\text { requirements of } \\
\text { the customer }\end{array}$ \\
\hline $\begin{array}{l}\text { Quality } \\
\text { level of } \\
\text { products }\end{array}$ & $\begin{array}{c}\text { The product } \\
\text { quality is very } \\
\text { low. } \\
\text { The product } \\
\text { does not meet } \\
\text { the majority of } \\
\text { quality } \\
\text { requirements. } \\
\text { The lowest } \\
\text { quality } \\
\text { compared to the } \\
\text { competition }\end{array}$ & $\begin{array}{l}\text { Most of the } \\
\text { product does not } \\
\text { meet the } \\
\text { requirements } \\
\text { and quality } \\
\text { criteria }\end{array}$ & $\begin{array}{l}\text { The product } \\
\text { meets some of } \\
\text { the quality } \\
\text { requirements. } \\
\text { Overall quality } \\
\text { rating } \\
\text { unacceptable }\end{array}$ & $\begin{array}{l}\text { The product } \\
\text { meets most of } \\
\text { the } \\
\text { requirements. } \\
\text { The product } \\
\text { quality is at } \\
\text { a good level. } \\
\text { Quality rating } \\
\text { acceptable }\end{array}$ & $\begin{array}{l}\text { Product without } \\
\text { objections. } \\
\text { It meets all } \\
\text { expectations and } \\
\text { standards. } \\
\text { The highest } \\
\text { quality of goods } \\
\text { on the market }\end{array}$ \\
\hline
\end{tabular}


Cont. table 2.

\begin{tabular}{|c|c|c|c|c|c|}
\hline $\begin{array}{l}\text { Quality } \\
\text { guarantees }\end{array}$ & $\begin{array}{l}\text { The supplier } \\
\text { often provides } \\
\text { faulty products } \\
\text { and does not } \\
\text { accept } \\
\text { complaints. } \\
\text { The complaint } \\
\text { handling period } \\
\text { is very long }\end{array}$ & $\begin{array}{l}\text { The supplier is } \\
\text { reluctant to } \\
\text { consider } \\
\text { complaints with } \\
\text { often faulty } \\
\text { products. Long } \\
\text { waiting time for } \\
\text { decisions } \\
\text { regarding } \\
\text { complaints }\end{array}$ & $\begin{array}{l}\text { The supplier } \\
\text { considers most } \\
\text { of the } \\
\text { complaints of } \\
\text { his goods } \\
\text { positively, } \\
\text { however they } \\
\text { are rare. } \\
\text { Examination } \\
\text { period } \\
\text { comparable to } \\
\text { the competition }\end{array}$ & $\begin{array}{l}\text { The supplier } \\
\text { considers the } \\
\text { majority of } \\
\text { complaints } \\
\text { positively, } \\
\text { products very } \\
\text { rarely returned } \\
\text { to complaints. } \\
\text { The period of } \\
\text { consideration is } \\
\text { short }\end{array}$ & $\begin{array}{l}\text { The supplier } \\
\text { considers } \\
\text { complaints } \\
\text { immediately. } \\
\text { There are } \\
\text { isolated } \\
\text { instances of } \\
\text { complaining the } \\
\text { product }\end{array}$ \\
\hline $\begin{array}{l}\text { Certificates } \\
\text { and licenses }\end{array}$ & $\begin{array}{l}\text { Lack of } \\
\text { certificates. } \\
\text { No quality } \\
\text { management } \\
\text { system. Work } \\
\text { on the system } \\
\text { has not been } \\
\text { undertaken }\end{array}$ & $\begin{array}{l}\text { The supplier } \\
\text { does not have } \\
\text { a quality } \\
\text { management } \\
\text { system, } \\
\text { although work } \\
\text { on the system } \\
\text { has been } \\
\text { undertaken }\end{array}$ & $\begin{array}{l}\text { The supplier has } \\
\text { introduced a } \\
\text { quality } \\
\text { management } \\
\text { system. } \\
\text { The system has } \\
\text { been certified }\end{array}$ & $\begin{array}{l}\text { The supplier has } \\
\text { introduced } \\
\text { a quality } \\
\text { management } \\
\text { system. } \\
\text { The system has } \\
\text { been certified. } \\
\text { Activities in the } \\
\text { system are } \\
\text { without } \\
\text { reservations }\end{array}$ & $\begin{array}{l}\text { In addition to } \\
\text { the quality } \\
\text { management } \\
\text { system, } \\
\text { the supplier has } \\
\text { many additional } \\
\text { certificates or } \\
\text { an integrated } \\
\text { management } \\
\text { system }\end{array}$ \\
\hline $\begin{array}{l}\text { Maintaining } \\
\text { stock levels } \\
\text { for } \\
\text { a customer }\end{array}$ & $\begin{array}{c}\text { Lack of } \\
\text { possibility to } \\
\text { maintain the } \\
\text { stock of specific } \\
\text { goods for } \\
\text { a customer }\end{array}$ & $\begin{array}{l}\text { It is possible to } \\
\text { keep stocks of } \\
\text { specific goods } \\
\text { for a buyer only } \\
\text { in sporadic } \\
\text { cases and in } \\
\text { small quantities }\end{array}$ & $\begin{array}{l}\text { The possibility } \\
\text { to maintain the } \\
\text { stock of goods } \\
\text { for a buyer } \\
\text { applies to goods } \\
\text { designated by } \\
\text { the supplier and } \\
\text { in a specified } \\
\text { quantity }\end{array}$ & $\begin{array}{l}\text { A significant } \\
\text { possibility of } \\
\text { maintaining the } \\
\text { stock of goods } \\
\text { for a buyer. } \\
\text { Isolated cases } \\
\text { for individual } \\
\text { products where } \\
\text { this is not } \\
\text { possible }\end{array}$ & $\begin{array}{l}\text { High possibility } \\
\text { of maintaining } \\
\text { the stock of } \\
\text { goods for } \\
\text { a buyer. } \\
\text { All goods can } \\
\text { be kept in stock } \\
\text { for a buyer in } \\
\text { any quantity }\end{array}$ \\
\hline $\begin{array}{c}\text { Deliveries } \\
\text { on own } \\
\text { behalf }\end{array}$ & $\begin{array}{l}\text { The supplier } \\
\text { does not provide } \\
\text { transport, does } \\
\text { not have } \\
\text { a company car } \\
\text { or contracts } \\
\text { with courier } \\
\text { companies. } \\
\text { Only own } \\
\text { collection by the } \\
\text { buyer }\end{array}$ & $\begin{array}{c}\text { The supplier } \\
\text { does not provide } \\
\text { transport, does } \\
\text { not have } \\
\text { a company car } \\
\text { or contracts } \\
\text { with courier } \\
\text { companies. } \\
\text { Occasional } \\
\text { cases where the } \\
\text { supplier "drops" } \\
\text { the goods }\end{array}$ & $\begin{array}{c}\text { The supplier } \\
\text { does not provide } \\
\text { deliveries using } \\
\text { his own } \\
\text { transport, only } \\
\text { through courier } \\
\text { and forwarding } \\
\text { services }\end{array}$ & $\begin{array}{c}\text { The supplier } \\
\text { provides } \\
\text { delivery by } \\
\text { means of his } \\
\text { own transport, } \\
\text { in some cases it } \\
\text { is courier } \\
\text { services }\end{array}$ & $\begin{array}{l}\text { The supplier } \\
\text { provides } \\
\text { deliveries using } \\
\text { his own } \\
\text { transport - } \\
\text { up to several } \\
\text { times a day }\end{array}$ \\
\hline $\begin{array}{l}\text { Diversity of } \\
\text { assortment }\end{array}$ & $\begin{array}{l}\text { The assortment } \\
\text { is only basic. } \\
\text { Lack of } \\
\text { diversity }\end{array}$ & $\begin{array}{l}\text { The variety of } \\
\text { the assortment } \\
\text { is low, in rare } \\
\text { cases it is } \\
\text { possible to } \\
\text { deliver goods } \\
\text { from outside the } \\
\text { basic assortment }\end{array}$ & $\begin{array}{l}\text { Variety of } \\
\text { assortment is } \\
\text { moderate, } \\
\text { in many cases } \\
\text { there is the } \\
\text { possibility of } \\
\text { delivering goods } \\
\text { from outside the } \\
\text { basic } \\
\text { assortment. } \\
\text { Diversity } \\
\text { comparable to } \\
\text { the competition }\end{array}$ & $\begin{array}{l}\text { Variety of } \\
\text { assortment high. } \\
\text { A wide range of } \\
\text { assortment, } \\
\text { and in case of } \\
\text { willingness to } \\
\text { buy goods from } \\
\text { outside the } \\
\text { range, there is } \\
\text { a possibility of } \\
\text { delivery }\end{array}$ & $\begin{array}{l}\text { Diversity of the } \\
\text { assortment is } \\
\text { very high. } \\
\text { A wide range of } \\
\text { assortment. } \\
\text { There is a high } \\
\text { possibility of } \\
\text { delivery of } \\
\text { goods from } \\
\text { outside the } \\
\text { assortment }\end{array}$ \\
\hline
\end{tabular}


Cont. table 2.

\begin{tabular}{|c|c|c|c|c|c|}
\hline $\begin{array}{c}\text { Technical } \\
\text { capabilities }\end{array}$ & $\begin{array}{c}\text { Lack of } \\
\text { technical } \\
\text { possibilities. } \\
\text { No purchase } \\
\text { option by design }\end{array}$ & $\begin{array}{c}\text { Low technical } \\
\text { capabilities. } \\
\text { Low purchase } \\
\text { options by } \\
\text { design }\end{array}$ & $\begin{array}{c}\text { Moderate } \\
\text { technical } \\
\text { possibilities. } \\
\text { Possibilities of } \\
\text { realisation only } \\
\text { some orders } \\
\text { according to the } \\
\text { project }\end{array}$ & $\begin{array}{c}\text { Big technical } \\
\text { possibilities. } \\
\text { Possibilities of } \\
\text { realising most } \\
\text { orders according } \\
\text { to the project }\end{array}$ & $\begin{array}{c}\text { Very big } \\
\text { technical } \\
\text { possibilities. } \\
\text { Possibilities of } \\
\text { realising all } \\
\text { orders according } \\
\text { to the project }\end{array}$ \\
\hline $\begin{array}{c}\text { Financial } \\
\text { possibilities }\end{array}$ & $\begin{array}{c}\text { Very poor } \\
\text { financial } \\
\text { condition of the } \\
\text { supplier. On the } \\
\text { verge of } \\
\text { bankruptcy }\end{array}$ & $\begin{array}{c}\text { Low financial } \\
\text { condition of the } \\
\text { supplier. There } \\
\text { is no certainty } \\
\text { of order } \\
\text { fulfilment }\end{array}$ & $\begin{array}{c}\text { Moderate } \\
\text { financial } \\
\text { condition of the } \\
\text { supplier }\end{array}$ & $\begin{array}{c}\text { Good financial } \\
\text { condition of the } \\
\text { supplier. } \\
\text { The supplier is } \\
\text { well protected }\end{array}$ & $\begin{array}{c}\text { Very good } \\
\text { financial } \\
\text { condition of the } \\
\text { supplier. } \\
\text { The supplier is } \\
\text { very well } \\
\text { protected }\end{array}$ \\
\hline
\end{tabular}

The proposal to introduce a new system for assessing solution providers puts much higher demands on suppliers. It was proposed to introduce more categories of suppliers' classification and to introduce the status of reserve supplier, which can be evaluated at the next periodic assessment and can become a qualified supplier. Setting a weighting to the criteria and changing the scale of assessment of the evaluation criteria will allow a more accurate assessment of potential suppliers. All of these solutions in the proposed evaluation method will allow the company to make the best choice.

\section{Summary}

An important element of the logistics system in the enterprise is the supply subsystem. Its primary objective is to secure production by satisfying the material needs of the company while reducing the costs of this process, so as to ensure its flow and avoid stagnation. Due to the fact that regardless of the business profile, all enterprises make purchases of goods on the market, therefore, all purchasing decisions should be taken with caution taking into account the level of costs incurred and profits achieved. The supplier's assessment should be carried out periodically, then the company will be able to pay attention to whether the given supplier continues to meet its requirements, identify the strengths and weaknesses of the supplier and propose corrective actions if any breaches are detected, and introduce improvement actions.

Regardless of the supplier's assessment method chosen, it is necessary to prepare a list of criteria appropriate for the business sector that will be the basis for starting the qualification process. The development of an appropriate supplier assessment method is one of the ongoing activities of continuous improvement in the company. 


\section{References}

1. Bendkowski, J., and Kramarz, M. (2011). Logistyka stosowana. Metody, techniki, analizy. Część I. Gliwice: Wydawnictwo Politechniki Śląskiej.

2. Bozarth, C., and Handfield, R.B. (2007). Wprowadzenie do zarzadzania operacjami i łańcuchem dostaw. Wydawnictwo OnePress.

3. Burdzik, R. (2017). Parametryczna ważona ocena dostawców. Prace Naukowe Politechniki Warszawskiej.

4. Kowalska, K. (2005). Logistyka zaopatrzenia. Wydawnictwo Akademii Ekonomicznej im. Karola Adamieckiego w Katowicach.

5. Kuczyńska-Chałada, M., Furman, J. (2016 May $\left.25^{\text {th }}-26^{\text {th }}\right)$. The process of improvement with the application of lean manufacturing in a steel company. 25th Anniversary International Conference on Metallurgy and Materials, Brno, 1782-1786.

6. Małysa, T. (2019). Work safety during usage, repair and maintenance of machines a review of work safety in the aspect of accidents at work. New trends in production engineering. In: T. Frączek (ed.), Selected aspects of production engineering in management and materials engineering (pp. 151-161). Warszawa: Sciendo.

7. Nowakowski, T., and Werbińska-Wojciechowska, S. (2012). Przegląd metod ocen i wyboru dostawców w przedsiębiorstwie. Logistyka, Vol. 2, 945-955.

8. Odlanicka-Poczobutt, M. (2016). Modelowanie relacji z dostawca na baize doświadczeń CRM - badania ankietowe.

9. Skowronek, Cz., Szajrusz-Wolski, Z. (2008). Logistyka w przedsiębiorstwie. Zeszyty Naukowe Politechniki Ślaskiej, z. 89. Polskie Wydawnictwo Ekonomiczne, 379-393.

10. Wolniak, R., and Skrotnicka-Zasadzień, B. (2008). Wybrane metody badania satysfakcji klienta i oceny dostawców w organizacjach. Wydawnictwo Politechniki Śląskiej.

11. Zakrzewski, B., Zakrzewska, D. (2014). Rola zaopatrzenia i metodyka wyboru dostawcy w działalności przedsiębiorstw przemysłowych. Logistyka, Vol. 3, 6977-6999. 